\title{
Generasi Berikutnya: Sel Punca Mesenkim Sebagai Sistem Penghantaran Obat Berbasis Sel
}

\author{
Adinda Christianti Suparno*, Nabila Rubinadzari, Ahsanal Kasasiah
}

Program Studi Sarjana Farmasi, Fakultas Ilmu Kesehatan, Universitas Singaperbangsa Karawang Jawa

Barat, Indonesia

*E-mail: adindachrst@gmail.com

(Submit 30/10/2021, Revisi 25/01/2022, Diterima 05/03/2022, Terbit 10/03/2022)

\section{Abstrak}

Mesenchymal Stem Cells (MSCs) atau sel punca mesenkim merupakan sel punca dewasa yang bersifat multipoten unik yang berasal dari sumsum tulang. MSCs memiliki sifat regeneratif yang luas dan imunomodulator yang dapat digunakan dalam perbaikan jaringan dan penyembuhan luka. MSCs juga mampu bermigrasi ke tempat peradangan, lokasi jaringan yang cedera, infeksi, dan tumor dengan imunomodulasi lingkungan mikro melalui kontak sel ke sel dan pelepasan faktor terlarut sehingga memfasilitasi adanya perbaikan pada jaringan yang rusak serta merespons kemokin, sitokin, dan faktor pertumbuhan. Berkat adanya karakteristik tersebut MSCs mulai gencar dikembangkan sebagai vektor terapi gen untuk berbagai penyakit termasuk kanker, IDD, epilepsi, gangguan pendengaran sensorineural hingga stroke iskemik. Metode yang digunakan dalam artikel review ini yaitu dengan melakukan peninjauan terhadap literatur, sehingga di dapatkan 6 jurnal internasional yang diperoleh dari PubMed dan ScienceDirect yang telah memenuhi kriteria inklusi, sumber data dipublikasi paling lambat 10 tahun terakhir. Dari beberapa hasil penelitian praklinis yang dilakukan, ditemukan bahwa MSCs memiliki potensi untuk dikembangkan sebagai sistem penghantaran obat berbasis sel generasi berikutnya, yang menjanjikan dalam terapi penyakit glioblastoma, gangguan pendengaran sensorineural, kanker kolekteral, epilepsi, stroke iskemik dan Intervertebral Disc Degeneration (IDD). Namun pada pengembangannya masih ditemui adanya tantangan dalam sistem tersebut, sehingga MSCs saat ini masih memerlukan penelitian lebih lanjut agar ke depannya dapat digunakan secara optimal sebagai sistem penghantaran obat serta dapat dikembangkan secara lebih luas.

Kata kunci: Eksosom, Mesenchymal Stem Cells, Nano Vesikel, Sel Punca Mesenkim, Sistem Penghantaran Obat

\section{Pendahuluan}

Keuntungan terapeutik obat yang diberikan sebagian besar dipengaruhi oleh konsentrasinya pada jaringan yang sakit, dimana distribusi obat yang tidak spesifik bukan hanya dapat mempengaruhi hasil pengobatan tetapi juga dapat menginduksi adanya potensi toksisitas. ${ }^{1}$ Selain itu, untuk agen biologis seperti protein, peptida dan 
asam nukleat, memerlukan perlindungan untuk memastikan stabilitasnya sebelum sampai ke target jaringan yang sakit. ${ }^{2}$ Pengembangan sistem penghantaran obat (SPO) dinilai sangat penting untuk memungkinkan pengiriman obat yang ditargetkan pada jaringan yang sakit dengan sangat efisien, dengan menawarkan lingkungan pemuatan yang memiliki kestabilan yang baik dan meminimalkan timbulnya efek samping. ${ }^{3}$

Hingga saat ini, adanya kemajuan dalam ilmu material science, ${ }^{4}$ nanotechnology, ${ }^{3}$ cellular engineering, 5,6 dan genetic recombination technology telah memperluas dan memperkaya peluang dalam mengembangkan sistem penghantaran obat (SPO). Kemajuan yang lebih baru dalam sito-biologi, terapi seluler telah memperkenalkan sebuah konsep baru tentang pemanfaatan sel hidup sebagai suatu vektor dalam sistem penghantaran obat.8,9 Antusiasme yang sangat besar terkait potensi terapi berbasis sel dalam mengobati beragam indikasi patologis merupakan suatu kemajuan dalam perkembangan teknologi rekayasa sel dengan atribut yang spesifik, semakin matang dan bahkan dalam beberapa kasus mulai memasuki tahap pengujian praklinis dan klinis. ${ }^{10}$

Salah satu sel yang menarik perhatian dalam pengembangan SPO adalah sel punca (stem cells). Sel punca muncul sebagai salah satu pilihan yang menarik karena kemampuan intrinsik yang dimilikinya sebagai vektor dalam penghantaran obat ke jaringan yang sakit. Istilah sel punca atau stem cells pertama kali diperkenalkan oleh ahli histologi berkebangsaan Rusia, Alexander Maksimov (1874 - 1928), pada kongres hematologi tahun 1908 yang diselenggarakan di Berlin. la memberikan hipotesis terkait sel punca yang dapat membentuk sel-sel darah. Kemudian tahun 1978 teori tersebut berhasil dibuktikan dengan ditemukannya sel-sel punca di sumsum tulang belakang manusia yang memiliki kemampuan dalam membentuk seluruh jenis sel darah yang terdapat dalam tubuh manusia. ${ }^{11}$ Sekitar pertengahan 2008 sel punca atau stem cells mulai semakin populer digunakan dalam bidang kedokteran. Selanjutnya sel punca berdasarkan tempat asalnya terdiri dari beberapa jenis termasuk hematopoietic stem cells, mesenchymal stem cells (MSCs), neural stem cells. ${ }^{6}$

Di antara semua jenis, Mesenchymal Stem Cells (MSCs) merupakan sel punca yang memiliki potensi lebih besar untuk dikembangkan, hal ini didasarkan oleh sumber daya yang melimpah, mudah dikembangkan secara in vitro, imunogenitas rendah, potensi diferensiasi multipoten, memiliki kemampuan untuk dimanipulasi atau dimodifikasi secara genetik serta menimbulkan lebih sedikit masalah etik dibandingkan dengan jenis sel punca lainnya. ${ }^{10,11}$ Selain itu MSCs memiliki sifat regeneratif yang luas dan imunomodulator yang dapat digunakan dalam perbaikan jaringan dan penyembuhan luka serta dapat berdiferensiasi menjadi garis keturunan osteogenik, kondrogenik, adipogenik ketika dikultur dalam media penginduksi tertentu. ${ }^{12}$ Karakteristik dasar yang dimiliki oleh MSCs salah satunya, merupakan sel punca yang paling mudah diakses dan diisolasi dari berbagai jaringan, seperti jaringan adiposa, tali pusat, tendon, kornea, timus, limpa, otak, hati, cairan ketuban, plasenta, pulpa gigi, dan sumber lainnya. ${ }^{12}$ Selain potensinya untuk berdiferensiasi menjadi adiposit, osteoblas, dan kondroplas, 
MSCs juga dapat berdiferensiasi menjadi turunan mesodermal,endodermal dan ektodermal lainnya seperti kardiomiosit, miosit skeletal, sel endotel, tenosit dan hepatosit, sel saraf, sel fotoreseptor, penghasil insulin, sel duktus epidermal dan sebasea, dan sel epitel tubulus ginjal. ${ }^{13} \mathrm{Hal}$ inilah yang kemudian mendorong MSCs sebagai suatu pilihan yang paling menarik perhatian dan memiliki potensi yang besar untuk dikembangkan sebagai Sistem Penghantaran Obat (SPO) berbasis sel.

\section{Metode}

Metode yang digunakan dalam artikel review ini yaitu dengan melakukan peninjuan terlebih dahulu terhadap literatur yang digunakan, pengumpulan hasil penelitian yang telah dipublikasikan, melakukan skrining awal dan menganalis data yang telah dipilih dengan seksama. Literatur yang dipublikasikan dengan rentang tahun publikasi 2012 2021 digunakan sebagai sumber data ilmiah. Pencarian literatur didasarkan pada penggunaan kata kunci "Mesenchymal Stem Cells" dan "Drug Delivery System" yang diperoleh dari database PubMed dan ScienceDirect. Kriteria inklusi yaitu jurnal internasional dengan topik Mesenchymal Stem Cells sebagai sistem penghantaran obat, original research (animal studies), jurnal yang menunjukkan adanya potensi sebagai sistem penghantaran obat, tersedia dalam bentuk full text, sumber literatur review yang digunakan dipublikasikan 10 tahun terakhir. Kriteria eksklusi yaitu jurnal yang tidak berhubungan dengan topik Mesenchymal Stem Cells sebagai sistem penghantaran obat, jurnal tidak berbahasa Inggris, sumber literatur yang dipublikasikan tidak pada rentang tahun publikasi 2012 - 2021, review, invited review, mini review, perspective. Diperoleh 6 jurnal internasional yang memenuhi kriteria inklusi. Artikel review ini dibuat untuk mengetahui adanya potensi MSCs sebagai salah satu kandidat sistem penghantaran obat berbasis sel generasi berikutnya. Bagan alir pencarian literatur dapat dilihat pada Gambar 1.

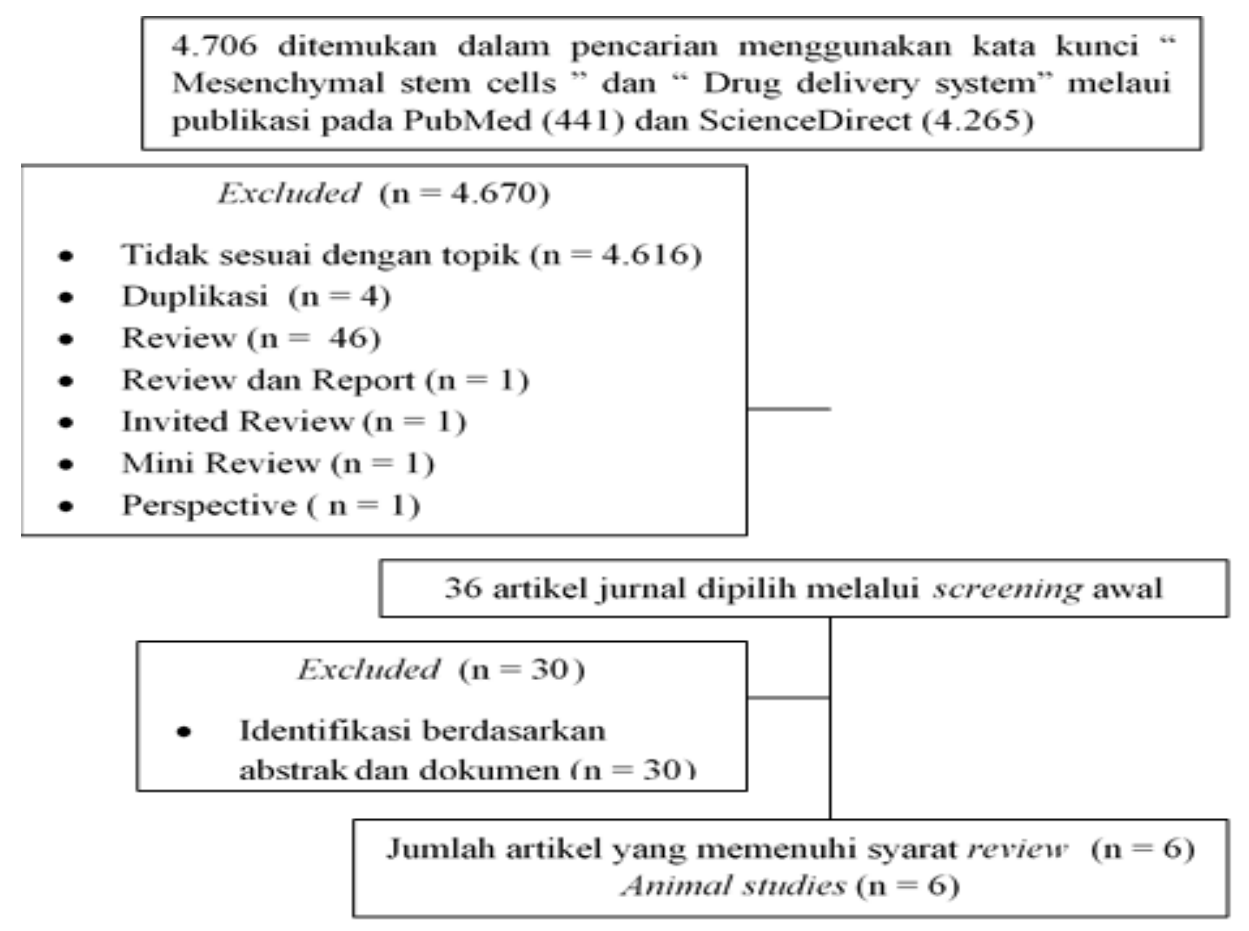

Gambar 1. Bagan alir pencarian literatur 


\section{Hasil dan Pembahasan}

Pada 6 studi yang diikutsertakan dalam artikel review ini telah memenuhi kriteria inklusi dan telah dilakukan serangkaian seleksi seperti yang terlihat pada Gambar 1.

Didapatkan sebanyak 6 uji praklinis dengan subjek penelitian berupa marmot, tikus dan mencit. Studi-studi terpublikasi dalam rentang waktu tahun $2012-2021$. Mode administrasi MSCs bervariasi mulai dari intranasal, intra-auricular, intravena, transplantasi, needle puncture. Berbagai detail karakteristik masing-masing studi dapat dilihat pada Tabel 1.

Tabel 1. Karakteristik masing-masing studi

\begin{tabular}{|c|c|c|c|c|c|}
\hline No & Referensi & Hewan Uji & Rute Pemberian & Dosis & Temuan Utama \\
\hline 1 & {$\left[{ }^{14}\right.$ ] } & $\begin{array}{l}\text { Female swiss } \\
\text { nude mice }\end{array}$ & Intranasal & $5.3 \mu \mathrm{g} / \mathrm{mice}$ & $\begin{array}{l}\text { MSCs sebagai vektor } \\
\text { SFN untuk terapi } \\
\text { model GB U78MG } \\
\text { dapat menghambat } \\
\text { pertumbuhan GB }\end{array}$ \\
\hline 2 & {$\left[{ }^{46}\right]$} & $\begin{array}{l}\text { Adult male } \\
\text { Dunkin - Hartley } \\
\text { guinea pigs }\end{array}$ & $\begin{array}{l}\text { Intra-auricular } \\
\text { menggunakan } \\
\text { sistem } \\
\text { mikrokateter }\end{array}$ & - & $\begin{array}{lr}\text { MSCs } & \text { yang } \\
\text { dimodifikasi } & \text { secara } \\
\text { genetik } & \text { dan } \\
\text { dienkapsulasi } & \text { dengan } \\
\text { UHV-alginat dapat } & \\
\text { meningkatkan } & \\
\text { kelangsungan } & \text { hidup } \\
\text { SGN pada hewan uji }\end{array}$ \\
\hline 3 & {$\left[{ }^{58}\right]$} & $\begin{array}{l}\text { Female } \quad B A L B / c \\
\text { mice }\end{array}$ & Intravena & $100 \mu \mathrm{l}$ & $\begin{array}{l}\text { Eksosomal MSCs yang } \\
\text { dimuat DOX bertarget } \\
\text { aptamer MUC1 } \\
\text { memberikan regresi } \\
\text { tumor sebesar } 65 \% \\
\text { pada hewan model } \\
\text { pembawa gen tumor } \\
\text { C26 }\end{array}$ \\
\hline 4 & {$\left[{ }^{65}\right]$} & $\begin{array}{l}\text { Male Sprague - } \\
\text { Dawley rats }\end{array}$ & Transplantasi & - & $\begin{array}{lr}\text { Transplantasi } & \text { HUMSC } \\
\text { menunjukkan } & \text { dapat } \\
\text { memberikan } & \\
\text { perlindungan } & \text { saraf } \\
\text { tambahan } & \text { dan } \\
\text { merangsang } & \\
\text { neurogenesis } & \end{array}$ \\
\hline
\end{tabular}




\begin{tabular}{|c|c|c|c|}
\hline $5 \quad\left[{ }^{75}\right]$ & $\begin{array}{l}\text { Sprague - Dawley Intravena } \\
\text { rats }\end{array}$ & $200 \mu \mathrm{g}$ & $\begin{array}{l}\text { MNV meningkatkan } \\
\text { kepadatan pembuluh } \\
\text { darah, menimbulkan } \\
\text { polarisasi makrofag } \\
\text { dari fenotipe M1 } \\
\text { inflamasi ke fenotipe } \\
\text { M2 anti-inflamasi, } \\
\text { menunjukkan volume } \\
\text { infark yang berkurang } \\
\text { secara signifikan serta } \\
\text { meningkatkan fungsi } \\
\text { motorik otak }\end{array}$ \\
\hline $\begin{array}{ll}6 & {\left[{ }^{83}\right]}\end{array}$ & $\begin{array}{l}\text { Male Sprague - Needle Puncture } \\
\text { Dawley rats }\end{array}$ & $100 \mu \mathrm{g} / \mathrm{mL}$ & $\begin{array}{l}\text { Metformin secara } \\
\text { efektif meningkatkan } \\
\text { sekresi EVs sebagai } \\
\text { sarana } \\
\text { mengoptimalkan } \\
\text { terapi IDD, dimana } \\
\text { EVs dapat } \\
\text { memberikan efek } \\
\text { antioksidan dan anti- } \\
\text { inflamasi untuk } \\
\text { meregenerasi sel } \\
\end{array}$ \\
\hline
\end{tabular}

\section{Mesenchymal Stem Cells untuk Terapi Glioblastoma}

Glioblastoma (GB) merupakan tumor otak primer yang paling umum, invasif dan agresif pada manusia. Hampir selama 12 tahun kebanyakan pasien penderita tumor GB telah diobati menggunakan Stupp protokol, ${ }^{14,15}$ yang terdiri dari reseksi bedah yang diikuti dengan radioterapi dan dibarengi dengan kemoterapi adjuvan temozolomide (TMZ). Dimana efektifitas dari terapi yang diberikan ini masih sangat terbatas, dengan rata-rata kelangsungan hidup keseluruhan tidak lebih dari 15 bulan. ${ }^{14,16}$ Pengobatan GB semakin diperumit dengan adanya resistensi tumor yang tinggi terhadap agen kemoterapi standar, adanya pertumbuhan dan penyebaran angiogenesis serta terdapatnya Blood Brain Barrier (BBB) yang berfungsi sebagai hambatan fisiologis untuk pengiriman obat ke sistem saraf pusat. Oleh karena itu, pengembangan obat tumor dan kanker yang inovatif yang menargetkan sel tumor dan pembuluh darah perlu dikembangkan. ${ }^{14}$

Dalam beberapa tahun terakhir, terapi molekuler yang ditargetkan pada sel tumor atau kanker dan pembuluh darah yang didasarkan pada penggunaan inhibitor dari beberapa jalur yang terlibat dalam proses onkogenik pada GB mulai bermunculan. ${ }^{17-19}$ Salah satunya adalah Sorafenib (SFN), yang merupakan salah satu inhibitor yang menargetkan reseptor kinase permukaan sel (VEGFR dan PDGFR) dan serin intraseluler atau treonin kinase. ${ }^{20}$ SFN menghasilkan efek seluler yang beragam, seperti induksi apoptosis sel tumor atau autophagy serta terjadinya reduksi 
angiogenesis. ${ }^{21,22}$ Namun, dengan adanya BBB, setiap obat yang akan ditargetkan menuju sistem saraf pusat, bekerja dengan tidak efisien, hal ini dikarenakan sulitnya obat tersebut secara fisik menembus BBB atau dengan kata lain obat tersebut tidak dapat menargetkan sel tumor.

Berbagai pendekatan mulai dikembangkan untuk mengatasi keterbatasan ini, salah satunya dengan penggunaan Mesenchymal stem cells (MSCs) sebagai vektor dalam pengobatan GB, dimana MSCs memiliki kemampuan untuk menembus BBB dengan mudah serta dapat menampilkan tropisme tumor otak setelah pemberian baik sistemik maupun lokal.23-27 MSCs telah dimodifikasi secara genetik untuk dapat mengekspresikan beberapa faktor antitumor seperti interleukin, interferon, pro-drugs, virus onkolitik, agen anti-angiogenik, protein pro-apoptosis dan antagonis faktor pertumbuhan. ${ }^{28,29}$ MSCs yang dimodifikasi mempunyai hasil yang menjanjikan pada model hewan uji tetapi masih terdapat resiko pada modifikasi genetik MSCs untuk aplikasi klinis. ${ }^{14}$ Oleh karena itu, beberapa penelitian menunjukkan bagaimana MSCs dapat mengirimkan obat kemoterapi ke sel tumor target tanpa adanya modifikasi genetik. ${ }^{30-34}$ Sebagai contoh, pada penelitian yang dilakukan sebelumnya menunjukkan bahwa MSCs dapat mengirimkan nanokapsul lipid yang mengandung ferrociphenol dalam model GB U87MG heterotopik dan ortotopik. 30,32,33 MSCs juga mampu melepaskan paclitaxel dan menginduksi kerusakan sitotoksik pada xenograft GB . 31,34,35 Injeksi bedah MSCs secara langsung ke sistem saraf pusat juga merupakan metode yang paling umum digunakan, namun metode tersebut bersifat invasif sehingga akan sulit apabila diperlukan pengobatan secara berulang. Oleh karena itu, dilakukan pendeketan lain terkait rute pemberian MSCs ke dalam SSP. Pemberian MSCs melalui rute intranasal menjadi sebuah alternatif yang menjanjikan dengan keunggulan seperti bersifat non invasif dan aman. ${ }^{36} \mathrm{MSC}$ s yang diberikan melalui rute intranasal memiliki kemampuan untuk menembus otak pada eksperimental model GB serta pada model tikus dengan penyakit Alzheimer, Parkinson dan model kerusakan otak iskemik neonatus. ${ }^{25,37,38}$

Pada penelitian sebelumnya dilakukan, evaluasi terkait kemampuan MSCs untuk mengambil SFN dan melepaskannya ke jaringan sel tumor dengan model GB U87MG ortotopik, dengan rute pemberian intranasal. Terdapat dua priming yang disiapkan yaitu MSCs $\left(4 \times 10^{5}\right)$ dengan SFN 20 $\mu \mathrm{M}(9.2 \mu \mathrm{g} / \mathrm{mL})$ dan MSCs $\left(4 \times 10^{5}\right)$ dengan SFN 100 $\mu \mathrm{M}(46 \mu \mathrm{g} / \mathrm{mL})$. dan dilakukan evaluasi pelepasan SFN dari waktu ke waktu $(4,24,48$, 72, 96 jam) menggunakan LC-MS/MS. Dari evaluasi tersebut didapatkan sekitar 20\% SFN-primed MSCs dilepaskan setelah 4 jam dan 60\% dilepaskan setelah 48 jam. Namun tidak terjadi peningkatan lebih lanjut untuk periode waktu inkubasi yang lebih lama, maka dari itu diperkirakan sekitar 40\% dari SFN dipertahankan oleh MSCs dan tidak dilepaskan. Setelah 3 hari SFN-primed MSCs, mampu melepaskan SFN sebesar $3.2 \mu \mathrm{g}$ yang selanjutnya diketahui dapat menurunkan kelangsungan hidup sel GB U87MG sebesar 23\%. ${ }^{14}$ Pada evaluasi yang dilakukan ditemukan bahwa konsentrasi SFN-primed MSCs $100 \mu \mathrm{M}$ menyebabkan toksisitas pada MSCs sebesar $40 \%$ sedangakan SFN-primed MSCs $20 \mu \mathrm{M}$ hanya bersifat sitotoksis sedang yaitu sekitar $20 \%$. Pada SFN-primed MSCs dengan konsentrasi $20 \mu \mathrm{M}$ mengandung dosis sekitar 9 
pg SFN per sel dan mampu melepaskan sekitar $60 \%$ obat ke dalam media kultur, dengan bergantung pada waktu. Aktivitas sitostatika dari SFN yang dilepaskan oleh MSCs mampu menghasilkan penghambatan signifikan sel U87MG dan poliferasi HUVEC secara in vitro. Pada pengujian menggunakan tikus pembawa GB U87MG selama 4 hari dengan menggunakan dua variasi SFN-primed MSCs secara intranasal di dapatkan hasil dapat mengurangi angiogenesis sel tumor, serta menghasilkan penurunan yang signifikan terhadap penurunan sejumlah besar pembuluh. Dalam penelitian ini tidak terlihat adanya penurunan volume pada sel tumor dikarenakan dosis SFN-primed MSCs (5.3 $\mu \mathrm{g} /$ tikus) yang diberikan tidak mencukupi. Dosis yang diberikan tersebut efektif dalam mengurangi kelangsungan hidup sel U87MG secara in vitro, tetapi kurang efektif terhadap sel U87MG secara in vivo hal ini dilatarbelakangi karena kurangnya dosis yang diberikan untuk dapat menimbulkan efek terapeutik yang diinginkan. Namun, cukup untuk mempengaruhi sel endotel yang empat kali lebih sensitif terhadap SFN. Dimana efek yang ditimbulkan oleh MSCs pada penghambatan pertumbuhan GB kemungkinan disebabkan oleh sifat pro-tumorigenik dan proangiogenik yang dimilikinya. ${ }^{14}$

\section{Mesenchymal Stem Cells untuk Perlindungan Neuron Auditori}

Cochlear Implant $(\mathrm{Cl})$ merupakan pengobatan standar untuk gangguan pendengaran sensorineural berat baik pada gangguan pendengaran unilateral maupun bilateral pada orang dewasa maupun anak-anak. Di seluruh dunia telah tercatat lebih dari 350.000 penderita gangguan pendengaran telah menerima $\mathrm{Cl} .{ }^{39}$ Hilangnya sel-sel rambut yang terkait dengan gangguan pendengaran diikuti dengan retraksi serabut saraf perifer pada model hewan uji ${ }^{40}$ dan pada manusia ${ }^{41,42}$ serta terjadinya degenerasi badan sel spiral ganglion neuron (SGN). ${ }^{41}$ Degenerasi sekunder ini sangat dipengaruhi oleh penyebab gangguan pendengaran dan struktur kerusakan koklea. Dimana jumlah SGN sangat berperan penting dalam tingkat keberhasilan pada $\mathrm{Cl}^{43}$ Dengan demikian pencegahan terkait degenerasi SGN merupakan suatu prioritas yang harus dilakukan agar meningkatkan keberhasilan dalam melakukan $\mathrm{Cl}$.

Stimulasi listrik SGN oleh CI diperkirakan dapat mengurangi degenerasi SGN melalui jalur pensinyalan neurotropik yang diinduksi depolarisasi. ${ }^{44}$ Namun sejauh mana stimulasi listrik mampu melindungi SGN dari degenerasi secara in vivo belum diketahui. Selain stimulasi listrik melalui $\mathrm{Cl}$, efek neuroprotektif pada SGN juga telah ditunjukkan untuk penerapan faktor neurotropik eksogen baik secara in vitro maupun in vivo. ${ }^{45}$ Namun, terapi neurotropik memerlukan pemberian berkelanjutan jika efek kelangsungan hidup (seumur hidup) ingin dicapai pada pasien. ${ }^{46}$ Oleh karena itu penggunaan pada terapi yang ditujukan untuk manusia harus dilakukan secara terusmenerus. Hal ini dinilai kurang praktis, karena pada pengaplikasiannya dilakukan secara berulang. ${ }^{47}$ Maka dari itu diperlukan pendekatan lain dalam mengatasi hal tersebut. 
Penghantaran obat berbasis sel menjadi suatu pendekatan baru dalam mengatasi kerusakan kronis pada neuron telinga bagian dalam. Inokulasi telinga bagian dalam dengan vektor yang sesuai dilakukan untuk mentransduksi sel koklea untuk mengekspresikan faktor neutropik yang diinginkan serta memungkinkan aplikasi yang stabil jika digunakan dalam jangka waktu yang panjang. ${ }^{48}$ Pendekatan lain untuk memasok faktor neurotropik berbasis sel ke dalam neuron telinga bagian dalam yaitu dengan cara implantasi sel autologus, alogenik, atau xenogenik. Sel yang ditanamkan dapat direkayasa secara genetik untuk mengekspresikan protein yang diinginkan atau untuk menghasilkan faktor pada konsentrasi neuroprotektif. Fibroblas yang diinduksi untuk memproduksi brain-derived neurotrophic factor (BDNF), suatu neurotropin, telah terbukti melindungi SGN dari degenerasi pada hewan uji marmot. ${ }^{49,50}$ Namun, sel-sel yang ditanamkan perlu terperangkap ke dalam suatu matriks untuk menghindari adanya migrasi yang tidak terkendali dan untuk melindungi dari sistem kekebalan sel induk. ${ }^{49}$ Enkapsulasi fibroblas ke dalam matriks alginat yang tidak biodegradable dan biokompatibel merupakan suatu pemecahan masalah. MSCs yang diperoleh dari manusia merupakan alternatif yang menjanjikan untuk dijadikan sebagai pengiriman faktor seumur hidup. MSCs dimodifikasi secara genetik, untuk mengekspresikan BDNF. Modifikasi MSCs secara genetik terbukti menghasilkan BDNF pada konsentrasi neuroprotektif secara in vitro. ${ }^{51}$

Kemudian ketika sel modifikasi MSCs ini dienkapsulasi dalam UHV-alginat, maka sel tersebut memiliki kemampuan untuk melindungi SGN dari degenerasi secara in vitro. Melapisi $\mathrm{Cl}$ dengan MSCs yang dienkapsulasi oleh UHV-alginat, secara terus menerus dapat mengekspresikan BDNF dan juga dapat meningkatkan kelangsungan hidup SGN pada hewan uji dengan gangguan pendengaran dibandingkan dengan implantasi koklea tanpa fungsionalisasi alginat-MSCs. ${ }^{46}$ Pelapisan $\mathrm{Cl}$ menggunakan MSCs yang dienkapsulasi oleh UHV-alginat terbukti dalam hal mempengaruhi kepadatan SGN ratarata dari seluruh koklea. ${ }^{46}$ Oleh karena itu, pelapisan $\mathrm{Cl}$ menggunakan MSCs yang dienkapsulasi oleh UHV-alginat menjadi metode yang layak untuk diterapkan dan dikembangkan dalam terapi faktor pertumbuhan pada gangguan pendengaran telinga bagian dalam.

\section{Mesenchymal Stem Cells untuk Terapi Kanker Kolekteral}

Pengembangan sarana yang efisien untuk pengiriman agen antikanker ke jaringan sel target kanker dengan toksisitas dan imunogenisitas rendah serta untuk memberikan efek peningkatan permeabilitas dan retensi (EPR) pada pembuluh darah pada kanker, merupakan tantangan yang harus dilakukan dalam pengembangan sistem penghantaran obat. ${ }^{52}$ Salah satu tren dan pendekatan penting untuk meningkatkan distribusi obat dan memperpanjang sirkulasinya salah satunya adalah cakupan pembawa obat oleh membran sel, seperti sel darah putih, ${ }^{53}$ sel darah merah, ${ }^{54}$ trombosit. ${ }^{55,56}$ Eksosom MSCs, merupakan sebuah partikel vesikular terikat membran berskala nano dengan ukuran mulai dari 30 hingga $200 \mathrm{~nm}$ yang disekresikan oleh berbagai jenis sel, contohnya seperti sel mamalia. ${ }^{22,57}$ Eksosom memiliki kemampuan yang menarik seperti stabilitas tinggi, imunogenisitas rendah, biokompatibilitas yang 
baik sehingga sangat berpotensi apabila digunakan sebagai pembawa obat alami. ${ }^{58}$ Selanjutnya, eksosom sebagai sarana transportasi biomimetik, yang diimplementasikan sebagai pembawa yang tepat untuk menyampaikan bahan terapeutik dengan cara yang aman atau yang disebut sebagai "eksocure". Dalam hal ini, eksosom telah banyak digunakan dalam kemoterapi 59

Dalam sebuah penelitian, formulasi eksosomal doksorubisin (DOX) yang direkayasa dikembangkan untuk memodifikasi biodistribusi dan farmakokinetik doksorubisin dan membantu mengurangi toksisitasnya. ${ }^{60}$ Terlepas dari pencapaian yang dapat dikatakan mengesankan ini, pemanfaatan eksosom sebagai sistem penghantaran obat menghadapi kendala utama yang cukup serius yaitu mengenai spesifisitas penargetan sel kanker yang kurang baik pada terapi kanker. Namun untuk mengatasi masalah ini, eksosom ditandai dengan berbagai ligan penanda tertentu. Dengan menandai eksosom dengan ligan penargetan, maka hal ini memungkinkan tercapainya pengiriman terpandu dari DOX yang dienkapsulasi ke sel target yang dapat mengurangi toksisitas sistemiknya. Enkapsulasi DOX ke dalam sistem penghantaran obat partikulat skala nano dapat memberikan biodistribusi yang menguntungkan, farmakokinetik, dan pelepasan terkontrol dan sekaligus dapat mengurangi toksisitas sistemiknya. ${ }^{61}$ Barubaru ini, eksosom sebagai vesikel bioinspired alami yang disekresikan dari sel yang berbeda telah digunakan untuk pengiriman berbagai terapi termasuk siRNA, taksol, doksorubisin dan pengiriman bersama gen dan obat. $.99,62,63$

Di antara banyak subtipe eksosom, eksosom yang diturunkan dari MSCs yang menghadirkan tropisme spesifik sel, biokompatibilitas yang diinginkan dan yang terpenting, imunogenisitas yang sangat rendah, serta berfungsi sebagai pembawa serbaguna untuk transportasi terapi ke lokasi aksi. ${ }^{64}$ Sifat inheren dari eksosom yang diturunkan dari MSC ini menjadikannya pembawa yang cocok untuk tujuan pengiriman obat. Dalam sebuah penelitian yang dilakukan sebelumnya, menunjukkan bahwa eksosom yang dimuat DOX menekan tingkat pertumbuhan tumor (regresi 30\%) pada nude mice pembawa tumor MDA-MB-231 sedangkan dalam penelitian ini, formulasi DOX bertarget aptamer MUC1 memberikan regresi tumor sebesar $65 \%$ pada tikus pembawa gen tumor C26. ${ }^{60}$ Adanya penurunan berat badan dan tingkat kelangsungan hidup hingga 22 hari pasca perawatan semakin menegaskan keamanan dan biokompatibilitas formulasi DOX yang bertarget aptamer MUC1.

\section{Mesenchymal Stem Cells untuk Terapi Epilepsi}

Epilepsi lobus temporal (ELT) adalah penyakit kronis yang ditandai dengan kejang spontan dan progresif. Pada banyak pasien, ELT diprakarsai oleh cedera otak, stroke, tumor atau status epileptikus (SE), yang sering diikuti oleh periode laten 5-10 tahun sebelumnya. 65 Serta timbulnya kejang motorik berulang spontan (SRMS). SE didefinisikan sebagai aktivitas kejang terus menerus yang berlangsung lebih dari 5 menit. Sedangkan SRMS adalah kejang berulang tanpa provokasi yang terjadi pada fase kronis epilepsi. Obat antiepilepsi gagal mengontrol kejang dengan baik pada sekitar $30 \%$ pasien epilepsi. ${ }^{65}$ Sehingga cangkok sel punca dianggap sebagai 
pendekatan alternatif yang menjanjikan pada pengobatan epilepsi untuk mendapatkan hasil pengobatan yang lebih baik. Dalam satu mekanisme, sel-sel punca yang ditransplantasikan dapat menggantikan sel-sel yang hilang karena adanya proses transdiferensiasi. Sel punca memiliki sifat dapat memperbaharui diri, dan kemampuan untuk berdiferensiasi menjadi tipe sel yang berbeda, yang dapat menggantikan sel yang hilang atau neuron spesifik selama epilepsi, seperti penghambat interneuron (inhibitory interneuron). 66

Sampai saat ini, penggunaan sel punca untuk menggantikan sel-sel yang hilang selama perjalanan epileptogenesis dianggap sebagai strategi yang efektif dalam pengobatan epilepsi. ${ }^{67,68}$ Human Umbilical Mesenchymal Stem Cells (HUMSCs) ini dapat berdiferensiasi menjadi sel neurogenik, osteogenik, kondrogenik, adipogenik, dan miogenik secara in vitro. Transplantasi HUMSCs secara efektif melindungi neuron dari atrofi, mencegah peradangan, dan memperbaiki penurunan kinerja motorik, yang kemungkinan disebabkan oleh kemampuan sel untuk menghasilkan faktor pendorong pertumbuhan. ${ }^{69}$ Selain efeknya pada sistem saraf pusat, transplantasi HUMSCs pada tikus dengan fibrosis hati dan fibrosis peritoneal juga menunjukkan potensi terapeutik yang menjanjikan melalui pelepasan sitokin. Hasil ini menunjukkan bahwa HUMSCs memiliki kemampuan bertahan hidup jangka panjang, dan mempertahankan fungsinya dalam berbagai organ inang tikus, hal inilah yang menjadi dasar HUMSCs sebagai sumber sel punca yang baik untuk xenotransplantasi.

Dalam penelitian yang dilakukan oleh Pei-Yu Huang et al., (2015), peneliti menyelidiki adanya potensi efek terapeutik HUMSC dalam model SE tikus yang diinduksi pilocarpine. Transplantasi HUMSC pada fase akut cedera otak eksitotoksik mencegah kerusakan jaringan pada periode laten dan menekan perkembangan SRMS. ${ }^{65}$ Pada penelitian yang dilakukan oleh Lee et al., (2014) menemukan bahwa frekuensi dan durasi kejang motorik berulang spontan pada hewan yang diinduksi pilocarpine berkurang dengan adanya transplantasi sel punca/progenitor saraf manusia (NSPCs) ke dalam hipokampus. Sel punca mesenkim sumsum tulang (BMSC) atau BMSC yang direkayasa secara genetik disuntikkan secara intravena, ditransplantasikan secara intra-ventrikular, atau ditanamkan langsung ke dalam hipokampus untuk mengevaluasi pemulihan tikus epilepsi yang diinduksi pilocarpine. ${ }^{70}$ Hasil penelitian menunjukkan bahwa jumlah kejang menurun secara signifikan, dan kepadatan neuron per area lebih tinggi pada kelompok transplantasi. ${ }^{71-73}$ Selain perlindungan saraf, transplantasi sel induk terapeutik juga dapat meningkatkan neurogenesis. Hasil mengungkapkan bahwa transplantasi sel punca untuk meningkatkan neurogenesis, dapat menjadi pendekatan terapeutik yang menjanjikan. Kemungkinan besar, pelepasan sitokin dari sel induk secara kritis mempengaruhi neurogenesis. Melalui penelitian yang dilakukan Pei-Yu huang et al., (2015), neuron hipokampus piramidal dan GABAergik yang diinduksi oleh SE secara signifikan berkurang dengan adanya transplantasi HUMSC. Transplantasi HUMSC menunjukkan dapat memberikan perlindungan saraf tambahan dan merangsang neurogenesis. 


\section{Mesenchymal Stem Cells untuk Terapi Stroke Iskemik}

Stroke iskemik adalah salah satu penyakit yang paling mematikan dan merupakan penyebab utama kecacatan jangka panjang. ${ }^{74}$ Peristiwa patologis utama dari stroke iskemik adalah iskemia otak yang disebabkan oleh oklusi pembuluh darah dan kerusakan saraf jaringan otak. Peradangan yang parah juga berkontribusi pada eksaserbasi cedera saraf dan disfungsi otak. Stres oksidatif yang disebabkan oleh iskemia dan reperfusi di jaringan otak mengaktifkan makrofag, sehingga melepaskan sitokin proinflamasi yang mengarah pada peradangan yang merugikan di lingkungan mikro otak.

Pemberian MSCs telah menarik perhatian luas untuk pengobatan stroke iskemik serebral. ${ }^{75}$ MSCs memiliki potensi besar untuk pengobatan stroke iskemik karena melepaskan biomolekul terapeutik yang menginduksi angiogenesis, anti-apoptosis, dan imunomodulasi. ${ }^{75,76}$ Namun, kesulitan untuk memberikan MSCs ke lesi stroke dapat membatasi penggunaan klinisnya untuk pengobatan stroke iskemik serebral. Implantasi intraserebral ke otak iskemik bersifat invasif dan dapat menyebabkan kerusakan tambahan pada jaringan otak normal. Pemberian intravena lebih sederhana dan kurang invasif dibandingkan dengan implantasi langsung. Namun, dikarenakan diameter MSCs yang besar $(15-40 \mu \mathrm{m})$, kapiler paru bertindak sebagai penghalang yang menangkap MSCs yang diberikan secara intravena. ${ }^{75}$ Oleh karena itu, untuk dapat mengatasi masalah terapi MSCs dalam pengobatan stroke iskemik digunakan eksosom yang diturunkan dari MSCs.

Eksosom adalah vesikel ekstraseluler yang mengandung berbagai mRNA, mikroRNA, dan protein yang berasal dari sel punca. Eksosom berukuran nanometer sehingga dapat melewati kapiler paru dan menghindari akumulasi di paru setelah pemberian secara intravena ke sistemik. ${ }^{77,78}$ Nano vesikel (NV) yang disiapkan menggunakan sel punca embrionik dengan metode ekstrusi menunjukkan peningkatan hasil produksi 250 kali lipat dibandingkan dengan eksosom yang disekresikan secara alami. ${ }^{79}$ Oleh karena itu, NV lebih menguntungkan daripada eksosom dalam hal produksi skala klinis.

Untuk mendapatkan NV dengan kemampuan penargetan yang baik, maka disiapkan Magnetic Nanovesicles (MNV) menggunakan MSC-IONP. MNV mengandung IONP yang dapat memediasi navigasi magnetik ke lesi iskemik pada otak dengan bantuan medan magnet eksternal (MF). IONP bersifat biokompatibel karena dapat diasimilasi oleh tubuh melalui ionisasi menjadi ion besi dan homeostasis besi. ${ }^{80}$ Pada penelitian yang telah dilakukan sebelumnya menunjukkan kelayakan NV yang diturunkan dari MSC dengan sifat magnetik untuk pengobatan stroke iskemik. MSC-IONP menunjukkan peningkatan ekspresi faktor pertumbuhan terapeutik yang menginduksi angiogenesis, anti-apoptosis, dan anti-inflamasi. MNV yang disiapkan menggunakan MSC-IONP mengandung sejumlah besar faktor pertumbuhan terapeutik dan IONP. Sifat magnetik yang dihasilkan oleh IONP memungkinkan MNV untuk menargetkan otak pada penyakit stroke iskemik dengan bantuan MF (magnetic field). MNV yang terakumulasi di otak iskemik meningkatkan kepadatan pembuluh darah, menimbulkan polarisasi makrofag dari fenotipe M1 inflamasi ke fenotipe M2 anti-inflamasi, dan akibatnya melemahkan 
kerusakan saraf pada lesi infark. Efek terapeutik yang ditimbulkan oleh MNV, menyebabkan adanya penurunan volume infark secara signifikan serta meningkatkan fungsi motorik otak. Oleh karena itu, terapi NV yang diturunkan dari MSC berpotensi untuk pengobatan stroke iskemik. ${ }^{75}$

\section{Mesenchymal Stem Cells untuk Terapi Intervertebral Disc Degeneration}

Intervertebral Disc Degeneration (IDD) merupakan salah satu gangguan muskuloskeletal yang tersebar luas di dunia, dimana penyebab utama IDD adalah nyeri punggung bagian bawah. ${ }^{81}$ Nyeri punggung terkait IDD mempengaruhi hingga $80 \%$ individu dalam melakukan aktivitas sehari-hari, hal ini kemudian dikaitkan dengan ekonomi yang berat dan beban sosial yang ditanggung. Sel NP (nucleus pulposus) yang terletak di pusat IVD (intervertebral disc) menghasilkan Extracellular Matrix (ECM), dan menjaga stabilitas struktural dan fungsional. Selama perkembangan IDD, terjadi perubahan utama pada sel-sel NP dimana sel tersebut mengalami transisi fenotipik dari profil normal ke senescent atau apoptosis, yang mengakibatkan penurunan sintesis ECM. ${ }^{82}$ Penuaan atau hilangnya sel NP secara bersamaan mempercepat perkembangan IDD. Peremajaan sel NP atau pemulihan viabilitas sel adalah tantangan kritis untuk regenerasi diskus intervertebralis. ${ }^{83}$

Metode terapi yang digunakan sampai saat ini untuk menangani IDD salah satunya yaitu perawatan bedah yang umumnya untuk meredakan gejala yang ditimbulkan. Selanjutnya terapi biologis untuk IDD berfokus pada regenerasi sel diskus yang menetap dan pemulihan sel yang cedera, sehingga dapat memberikan efek terapeutik jangka panjang. Mesenchymal Stem Cells (MSCs) dianggap sebagai strategi biologis potensial untuk perbaikan IDD, terutama dalam mengerahkan fungsi biologis antipenuaan atau anti-apoptosis melalui efek parakrinnya. ${ }^{84,85}$ Extracellular Vesicle (EVs) adalah sekresi vesikular parakrin MSCs yang memediasi efek biologis MSCs. Terapi EVs memberikan sejumlah keuntungan potensial, seperti biaya produksi yang lebih rendah, stabilitas yang lebih tinggi, lebih banyak kemudahan dalam perawatan sterilisasinya, penyimpanan dan dalam pengobatan dengan pemberian secara infus. ${ }^{84}$ EVs dianggap sebagai strategi alternatif yang menjanjikan untuk terapi MSCs. EVs yang diturunkan dari MSCs menunjukkan potensi terapeutik yaitu dalam perbaikan dan regenerasi jaringan. 83

Bukti yang berkembang menunjukkan efektivitasnya dalam menghambat perkembangan IDD dan berfungsi sebagai pengobatan yang efektif untuk IDD.86,87 Dalam penelitian yang dilakukan oleh Liao et al., (2021) menunjukkan bahwa metformin dapat digunakan sebagai sarana untuk mengoptimalkan terapi IDD berbasis MSCs, hal ini dikarenakan metformin secara efektif dapat meningkatkan sekresi EVs. Sekresi MSCs, termasuk EVs, memberikan efek antioksidan dan anti-inflamasi untuk meregenerasi sel-sel yang sudah tua yang ada dalam disk. EVs yang diturunkan dari MSCs sebagai terapi berbasis sel memberikan keunggulan spesifik dan aplikasi yang lebih nyaman. EVs memiliki kemampuan dalam melakukan perbaikan dan regenerasi jaringan dengan memberikan efek anti-inflamasi, anti-apoptosis, dan imunoregulasi. ${ }^{83}$ 


\section{Studi Komparatif Potensi MSCs sebagai Sistem Penghantaran Obat Berbasis Sel}

Potensi MSCs sebagai sistem penghantaran obat berbasis sel didasarkan pada pertimbangan kemanjuran dan keamanannya dalam suatu terapi. 88 Pada penelitian yang dilakukan oleh Clavreul et al., (2017) MSCs digunakan sebagai terapi glioblastoma dengan menggunakan rute intranasal menjadi salah satu alternatif yang menjanjikan dengan keunggulan bersifat non invasif, aman serta memiliki kemampuan untuk menembus BBB. Kemudian penggunaan MSCs pada terapi perlindungan neuron auditori secara intraauricular menggunakan sistem mikrokateter pada koklea menjadikannya sebagai suatu vektor untuk mentransduksi sel koklea dalam mengekspresikan faktor neutropik, selain itu penggunaannya berfungsi untuk menghindari adanya migrasi yang tidak terkendali serta melindungi dari sistem kekebalan sel induk. ${ }^{49}$ Kemudian penggunaan HUMSCs pada terapi epilepsi memiliki potensi yang menjanjikan hal ini terlihat dari penggunaannya, dimana transplantasi HUMSCs yang dilakukan pada fase cedera otak eksitotoksik berhasil mencegah kerusakan jaringan saraf, menekan perkembangan SRMS dan merangsang neurogenesis. Namun penelitian lain menyebutkan bahwa implantasi intraserebral ke otak iskemik bersifat invasif dan dapat menyebabkan kerusakan tambahan pada jaringan otak normal. ${ }^{75}$ Selanjutnya pada penelitian yang dilakukan oleh Bagheri et al., (2020) penggunaan eksosom turunan MSCs yang direkayasa dapat memodifikasi biodistribusi, farmakokinetik dan yang terpenting adalah menimbulkan imunogenitas yang rendah dan mengurangi toksisitasnya sehingga makin menegaskan keamanannya, selain itu penggunaan eksosom yang merupakan vesikel ekstraseluler yang terikat pada membran berskala nano dengan ukuran mulai dari $30-200 \mathrm{~nm}$ memberikan keuntungan seperti stabilitas yang lebih tinggi, imunogenitas rendah, biokompatibilitas yang baik. Terlepas dari pencapaian yang mengesankan, pemanfaatan eksosom memiliki kendala utama terkait spesifitas penargetan contohnya pada penelitian yang dilakukan oleh Bagheri et al., (2020) pada sel kanker, sehingga untuk mengatasi hal tersebut perlu dilakukan modifikasi yaitu dengan menandai eksosom dengan ligan penanda. Selain itu pada penelitian yang dilakukan oleh Kim et al., (2020) penggunaan nano vesikel menunjukkan peningkatan hasil produksi 250 kali lipat dibandingkan dengan eksosom yang diekskresikan secara alami sehingga lebih menguntungkan daripada eksosom dalam hal produksi. Kemudian penelitian yang dilakukan oleh Liao et al., (2021) pada terapi IDD menggunakan EVs yang diturunkan dari MSCs menunjukkan potensi terapeutik dalam perbaikan dan regenerasi jaringan. Namun masalah utama dari EVs adalah hasil produksi yang terbatas dan kualitas nano vesikel yang tidak stabil, yang menghambat aplikasi klinis EVs. Selanjutnya terbatasnya data yang digunakan dalam artikel review ini, sehingga saat ini hanya dapat menggambarkan potensinya namun belum cukup untuk menyimpulkan bentuk MSCs seperti apa yang memberikan sistem penghantaran obat berbasis sel yang optimal. 


\section{Kesimpulan}

Berdasarkan peninjauan, saat ini penelitian praklinik mengenai MSCs sebagai sistem penghantaran obat berbasis sel sudah mulai gencar dilakukan, hal ini terbukti dari beberapa penelitian yang telah dilakukan dengan menggunakan hewan uji, membuktikan bahwa MSCs memiliki potensi dalam terapi penyakit glioblastoma, gangguan pendengaran sensorineural, kanker kolekteral, epilepsi, stroke iskemik dan Intervertebral Disc Degeneration (IDD). Maka dari itu, MSCs memiliki potensi besar untuk dikembangkan menjadi sistem penghantaran obat berbasis sel yang menjanjikan bagi generasi berikutnya. Namun pada pengembangannya di beberapa penelitian masih ditemui adanya tantangan dalam sistem tersebut, salah satunya adanya modifikasi MSCs secara genetik yang dilakukan pada beberapa penelitian memberikan hasil yang menjanjikan pada model hewan uji namun masih terdapat resiko jika diaplikasikan secara klinis. Sehingga MSCs saat ini masih memerlukan penelitian lebih lanjut agar ke depannya dapat digunakan secara optimal sebagai sistem penghantaran obat serta dapat dikembangkan secara lebih luas, mengingat berbagai penelitian lanjutan terkait MSCs sampai saat ini masih terus dilakukan dan dikembangkan.

\section{Daftar Pustaka}

1. Huleihel L, Sellares J, J C, N A, D F, R S, et al. Modified mesenchymal stem cells using miRNA transduction alter lung unjury in a bleomycin model. Am J Physiol. 2017;313:L92-103.

2. Skalko-Basnet N. Biologics: the role of delivery systems in improved therapy. Biol Targets Ther. 2014;4(8):107-14.

3. Su Y, Zhang T, Huang T, Gao J. Current advances and challenges of mesenchymal stem cells-based drug delivery system and their improvements. Int J Pharm. 2021;1-10.

4. Ashton S, Song Y., Nolan J, Cadogan E, Murray J, Odedra R, et al. Aurora kinase inhibitor nanoparticles target tumors with favorable therapeutics index in vivo. Sci Transl Med. 2016;8(325):1-12.

5. Ayer M, Klok H. Cell-mediated delivery of synthetic nano and microparticles. J Control Release. 2017;259:92-104.

6. Thanuja M., Anupama C, Ranganath S. Bioengineered cellular and cell membrane-derived vehicle for actively targeted drug delivery: so near and yet so far. Adv Drug Deliv Rev. 2018;132:57-80.

7. Tariq I, Ali muhammad yasir, Sohail M., Amin M., Ali S, Bukhari N., et al. Lipodendriplexes mediated enhanced gene delivery: cellular to pre-clinical ivestigation. Sci Rep. 2020;10:21446.

8. Wang X, Gao J, Ouyang X, Wang J, Sun X, Lv Y. Mesenchymal stem cells loaded with paclitaxel-poly(lactic-co-glycolic acid) nanoparticles for glioma targeting therapy. Int J Nanomedicine. 2018;13:5231-48.

9. Ouyang X, Wang X, Kratz heinz bernhard, Ahmadi S, Gao J, Lv Y, et al. A trojan horse biomimetic delivery strategy using mesenchymal stem cells for PDT/PTT therapy againts lung melanoma metastasis. Biomater Sci. 2020;8:1160-70. 
10. Krueger TE., Thorek DL., Denmeade SR, Isaacs JT, Brennen WN. Concise Review: Mesenchymal Stem Cell-Based Drug Delivery: The Good, the Bad, the Ugly, and the Promise. 2018;651-63.

11. Hartono B. Sel Punca: Karakteristik, Potensi dan Aplikasinya. J Kedokt Meditek. 2016;22(60):72-5.

12. Sisca, Azizah N, Aldi M salas al. Potensial Mesenchymal stem cell-derived extracellular vesicles (MSC-EVS) sebagai terapi terbaru dalam iskemik retinal. Al lqra Med J. 2018;1(2):65-73.

13. Fajarwati S. Hambatan mesenchymal stem cells terhadap poliferasi limfosit T. J Biosains Pascasarj. 2018;20(3):212-25.

14. Clavreul A, Porbaghi-Masouleh M, Roger E, Lautram N, Montero-Menei claudia $\mathrm{N}$, Menei P. Human mesenchymal stromal cells as cellular drug-delivery vectors for glioblastoma theraphy: a good deal? J Exp Clin Cancer Res. 2017;36(135):111.

15. Stupp R, Mason W., M.J van den bent, Weller M, Fisher B, Taphoorn MJ. Radiotherapy plus concomitant and adjuvant temozolomide for glioblastoma. $\mathrm{N}$ Engl J Med. 2005;352:987-96.

16. Stupp R, Hegi ME, Mason WP, Bent MJ Van Den, Janzer robert C. Effects of radiotherapy with concomitant and adjuvant temozolomide versus radiotherapy alone survival in glioblastoma in a randomized phase III study: 5-year analysis of the EORTC-NCIC trial. Lancet Oncol. 2009;10:459-66.

17. Polivka J, Holubec L, Kubikova T, Priban V, Hes O, Pivovarcikova K, et al. Advances in experimental targeted therapy and immunotherapy for patients with glioblastoma multiforme. Anticancer Res. 2017;37(1):21-33.

18. Staedtke V, Bai R, Laterra J. Investigational new drugs for brain cancer. Expert Opin Investig Drugs. 2017;25:937-56.

19. Kang jennifer $\mathrm{H}$. Novel chemotherapeutics and other therapies for treating highgrade glioma. Expert Opin Investig Drugs. 2015;24(10):1361-79.

20. Wilhelm S, Carter C, Kelley S, Lynch M, Lowinger T, Dumas J, et al. Discovery and development of sorafenib: a multikinase inhibitor for treating cancer. Nat Rev Drug Discov. 2006;5:835-44.

21. Carra E, Barbieri F, Marubbi D, Pattarozzi A, Favoni RE, Florio T, et al. Sorafenib selectively depletes human glioblastoma tumor-initiating cells from primary cultures. Cell Cycle. 2013;12(3):491-500.

22. Siegelin markus D, Raskett CM, Gilbert CA, Ross AH, Altieri DC. Sorafenib exerts anti-glioma activity in vitro and in vivo. Neurosci Lett. 2010;478(3):165-70.

23. Roger M, Clavreul A, Sindji L, Chassevent A, Schiller PC, Montero-Menei CN, et al. in vitro and in vivo interactions between glioma and marrow-isolated adult multilineage inducible (MIAMI) cells. Brain Res. 2012;1473:193-203.

24. Mangraviti A, Tzeng S, Gullotti D, Kozielski KL, Kim JE, Seng M, et al. Non-virally engineered human adipose mesenchymal stem cells produce BMP4, target brain tumors, and extend survival. Biomaterials. 2016;100:53-6. 
25. Balyasnikova I v, Prasol MS, Ferguson SD, Zhang L. Intranasal Delivery of Mesenchymal Stem Cells Significantly Extends Survival of Irradiated Mice with Experimental Brain Tumors. Mol Ther. 2014;22(1):140-8.

26. Pacioni S, Giorgio Q, Giannetti S, Morgante L, Cocce V, Bonomi A, et al. Human mesenchymal stromal cells inhibit tumor growth in orthotopic glioblastoma xenografts. Stem Cell Resarch Ther. 2017;8(53):1-15.

27. Menon LG, Pratt J, Yang hong wei, M P, A G, S R. Imaging of human mesenchymal stromal cells: homing to human brain tumors. J Neurooncol. 2012;107:257-67.

28. Bhere D, Shah K. Stem Cell-Based Therapies for Cancer. Nat Rev Cancer. 2014;14:683-91.

29. Namba $\mathrm{H}$, Kawaji $\mathrm{H}$, Yamasaki T. Use of genetically engineered stem cells for glioma therapy. Oncol Lett. 2016;11:9-15.

30. Roger M, Clavreul A, Huynh N trinh, Passirani C, Schiller P, Vessieres A, et al. Ferrociphenol lipid nanocapsule delivery by mesenchymal stromal cells in brain tumor therapy. Int J Pharm. 2012;423(1):63-8.

31. Pacioni S, D'Alessandris Q, Giannetti S, Morgante L, De PI, Cocce V. Mesenchymal stromal cells loaded with paclitaxel induce cytotoxic. Stem Cell Resarch Ther. 2015;6(194):1-11.

32. Li L, Guan Y, Liu H, Hao N, Liu T, Meng X, et al. Silica nanorattle-doxorubixicinanchored mesenchymal stem cells for tumor-tropic therapy. ACS Nano. 2011;5:7462-70.

33. Clavreul A, Montagu A, Laine A-L, Tetaud C, Lautram N, Franconi F. Targeting and treatment of glioblastomas with human mesenchymal stem cells carrying ferrociphenol lipid nanocapsules. Int J Nanomedicine. 2015;10:1259-71.

34. Zhang X, Yao S, Liu C, Jiang Y. Tumor tropic delivery of doxorubicin-polymer conjugates using mesenchymal stem cells for glioma therapy. Biomaterials. 2015;39:269-81.

35. Pessina A, Bonomi A, Cocce V, Invernici G, Navone S, Cavicchini L, et al. Mesenchymal stromal cells primed with paclitaxel provide a new approach for cancer therapy. PLoS One. 2011;6(12):e28321.

36. Danielyan L, Schafer R, Ameln andreas von, Buadze M, Geisler J, Klopfer T, et al. Intranasal delivery of cells to the brain. Eur J Cell Biol. 2009;88(6):315-24.

37. Danielyan L, Hammer B, Stolzing A, Schafer R, Siegel G, Fabian C, et al. Intranasal delivery of bone marrow-derived mesenchymal stem cells, macrophages, and microglia to the brain in mouse models of Azheimer's and Parkinson's disease. Eur J Cell Biol. 2014;23:S123-139.

38. Velthoven cindy TJ Van, Kavelaars A, Bel frank Van, Heijnen CJ. Nasal administration of stem cells: a promising novel route to traet neonatal ischemic brain damage. Pediatr Res. 2010;68:419-22.

39. NIDCD. Cochlear implants. Bethesda, MD: National Institute of Health/National Institute on Deafness and Other Communication Disorders. 2017.

40. Zilberstein $Y$, Liberman $C$, Corfas $G$. Inner hair cells are not required for survival of spiral ganglion neurons in the adult cochlea. J Neurosci. 2012;32(2):405-10. 
41. Liu W, Edin F, Atturo F, Rieger G, H L, P S, et al. The pre- and post-somatic segments of the human type I spiral ganglion neurons-structural and functional considerations related to cochlear implantation. Neuroscience. 2015;284:470-82.

42. Whitlon DS. Drug discovery for hearing loss: phenotypic screening of chemical compunds on primary cultures of the spiral ganglion. Hear Res. 2017;349:177-81.

43. Seyyedi M, Viana LM, Nadol JBJ. Within-subject comparison of word recognition and spiral ganglion cell count in bilateral cochlear implant recipient. Otol Neurotol. 2014;35(8):1446-50.

44. Leake patricia A, Stakhovskaya O, Hetherington A, Rebscher SJ, Bonham B. Effects of brain-derived neurotrophic factor (BDNF) and electrical stimulation on survival and function of cochlear spiral ganglion neurons in deafened, developing cats. J Assoc Reasearch Otolaryngol. 2013;14:187-211.

45. Leake patricia A, Hradek GT, Hetherington A, Stakhovskaya O. Brain-derived neurotrophic factor promotes cochlear spiral ganglion cell survival and functions in deafened, developing cats. J Comp Neurol. 2011;519(8):1526-45.

46. Scheper V, Hoffmann A, M.Gepp M, Schulz A, Hamm A, Pannier C, et al. Stem cell based drug delivery for protection of auditory neurons in a guinea pig model of cochlear implantation. Front Cellulsr Neurosci. 2019;13:177.

47. Prenzler NK, Salcher R, Timm M, Gaertner L, Lenarz T, Warnecke A. Intracochlear administration of steroids with a catheter during human cochlear implantation: a safety and feasibility study. Drug Deliv TransI Res. 2018;8:1191-9.

48. David RM, Doherty AT. Viral vectors: the road to reducing genotoxicity. Toxicol Sci. 2017;155(2):315-25.

49. Warnecke A, Sasse S, Wenzel GI, Hoffman A, Gross G, Paasche G, et al. Stable release of BDNF from the fibroblast cell line NIH3T3 grown on silicone elastomers enhances survival of spiral ganglion cells in vitro and in vivo. Hear Res. 2012;289(1-2):86-97.

50. Gillespie LN, Zanin MP, Shepherd RK. Cell-based neurotrophin treatment supports long-term auditory neuron survival in the deaf guinea pig. J Control Release. 2015;198:26-34.

51. Hutten M, Dhanasingh A, Hessler R, Stover T, Esser K, Moller M, et al. In vitro and in vivo evaluation of a hydrogel reservoir as a continuous drug delivery system for inner ear treatment. PLoS One. 2014;9(8):e104564.

52. Zhang Y, Chen Y, Lo C, Zhuang J, Angsantikul P, Zhang Q, et al. Inhibition of pathogen adhesion by bacterial outer membrane-coated nanoparticles. Angew Chemie Int Ed. 2019;58(33):11404-8.

53. Parodi A, Quattrocchi N, L A, Chiappini C, Evangelopoulos M, O J, et al. Synthetic nanoparticles functionalized with biomimetic leukocyte membranes possess celllike functions. Nat Nanotechnol. 2013;8:61-8.

54. Piao J, Wang L, Gao F, You ye zi, Xiong Y, Yang L. Erythrocyte membrane is an alternative coating to polethylene glycol for prolonging the circulation lifetime of gold nanocages for photothermal therapy. ACS Nano. 2014;8(10):10414-25. 
55. Chen Z, Zhao P, Luo Z, Zheng M, Tian H, Gong P, et al. Cancer cell membranebiomimetic nanoparticles for homologous-targeting dual-modal imaging and photothermal therapy. ACS Nano. 2016;10(11):10049-57.

56. Wei X, Gao J, H R, T B, V A, Dehaini D, et al. Nanoparticles camouflaged in platelet membrane coating as an antibody decoy for the treatment of immune thrombocytopenia. Biomaterials. 2016;111:116-23.

57. Mirzael H, Sahebkar A, Jaafari mahmoud reza, Goodarzi M, Mirzael hamid reza. Diagnostic and therapeutic potential of exosomes in cancer: the beginning of a new tale? J Cell Physiol. 15384BC;232(12):3251-60.

58. Bagheri E, Abnous K, Farzad sara amel, Taghdisi seyed mohammad, Ramezani M, Alibolandi M. Targeted doxorubicin-loaded mesenchymal stem cells-derived exosomes as a versatile platform for fighting againts colorectal cancer. Life Sci. 2020;261:118369.

59. Schindler C, Collinson A, Matthews C, Pointon A, Jenkinson L, R R, et al. Exosomal delivery of doxorubicin enables rapid cell entry and enhanced in vitro potency. PLoS One. 2019;14(3):1-19.

60. Hadla M, Palazzolo S, Corona G, Caligiuri I, Canzonieri V, Toffoli G, et al. Exosome increase the therapeutic index of doxorubicin in breast and ovarian cancer mouse models. Nanomedicine. 2016;11(18):2431-41.

61. Alibolandi M, Abnous K, Mohammadi M, Hadizadeh F, Sadeghi F, Taghavi S, et al. Extensive preclinical investigation of polmersomal formulation of doxorubicin versus Doxil-mimic formulation. J Control Release. 2017;264:228-36.

62. Alvarez L, Seow Y, Yin H, Betts C, Lakhal S, J M. Delivery of siRNA to the mouse brain by systemic injection of targeted exosomes. Nat Biotechnol. 2011;29:341-5.

63. Melzer C, Rehn V, Yang Y, Bahre H, Ohe juliane Von der, Hass R. Taxol-loaded MSC-derived exosomes provide a therapeutic vehicle to target metastatic breast cancer and other carcinoma cells. Cancers (Basel). 2019;11(6):798.

64. Kalluri R, Lebleu VS. The biology, function and biomedical applications of exosomes. Science (80- ). 2020;367(6478):1-40.

65. Huang pei yu, Shih yang hsin, Tseng yi jhan, Ko tsui ling, Fu yu show, Lin yung yang. Xenograft of human umbilical mesenchymal stem cells from Wharton's jelly as a potential therapy for rat pilocarpine-induced epilepsy. Brain, Behav an Immun. 2016;54:45-58.

66. Roper SN, Steindler DA. Stem cells as a potential therapy for epilepsy. Exp Neurol. 2013;244:59-66.

67. Cunningham M, Cho jun hyeong, Leung A, Kim kwang soo, Bolshakov vadim y, Chung S. hPSC-derived maturing GABAergic interneurons ameliorate seizures and abnormal behavior in epileptic mice. Cell Stem Cell. 2014;15:559-73.

68. Hunt RF, Girskis KM, Rubenstein JL, Alvarez A, Baraban SC. GABA progenitors grafted into the adult epileptic brain control seizures and abnormal behavior. Nat Neurosci. 2013;16:692-7.

69. Lin yu ching, Ko M. tsui ling, Shih yang hsin, Lin maan yuh anya, Fu T win, Hsiao hsiao sheng, et al. Human umbilical mesenchymal stem cells promote recovery after ischemic stroke. Stroke. 2011;42:2045-53. 
70. Lee H, Yun S, Kim I, Lee I, Shin jeong eun, Park soo chul, et al. Human fetal brain-derived neural stem/progenitor cells grafted into the adult epileptic brain restain seizures in rat models of temporal lobe epilepsy. PLoS One. 2014;9(8):e104092.

71. Costa-ferro ZS., Souza BS., Leal MM., Kaneto C martins, Machado C, Campos I, et al. Transplantation of bone marrow mononuclear cells decreases seizure incidence, mitigates neuronal loss and modulate pro-inflammatory cytokine production in epileptic rats. Neurobiol Dis. 2012;46(2):302-13.

72. Huicong $\mathrm{K}$, Zheng $\mathrm{X}$, Furong $\mathrm{W}$, Zhouping $\mathrm{T}$, Feng $\mathrm{X}$, Qi H, et al. The imbalanced expression of adenosine receptors in an epilepsy model corrected using targeted mesenchymal stem cell transplantation. Mol Neurobiol. 2013;48:921-30.

73. Leal marcus mauricio tosta, Munhoz zaquer suzana, Solano B, Machado C, Meneses $\mathrm{T}$, Kaneto $\mathrm{C}$ martins, et al. Early transplantation of bone marrow mononuclear cells promotes neuroprotection and modulation of inflammatory after status epilepticus in mice by paracrine mechanism. Neurochem Res. 2014;39:259-68.

74. Chen L, Zhang G, Khan ahsan ali, Guo X, Gu Y. Clinical Efficacy and metaanalysis of stem cell therapies for patients with brain ischemia. Stem Cells Int. 2016;2016(6129579).

75. Kim han young, Kim tae jung, Kang L, Kim young ju, Kang min kyoung, Kim J, et al. Mesenchymal stem cell-derived magnetic extracellular nanovesicles for targeting and treatment of ischemic stroke. Biomaterials. 2020;243(119942).

76. Zhang T, Lee yuk wai, Rui yun feng, Cheng tin yang, Jiang xiao hua, Li G. Bone marrow-derived mesenchymal stem cells promote growth and angiogenesis of breast and prostate tumors. Stem Cell Resarch Ther. 2013;4(70):1-15.

77. Raposo G, Stoorvogel W. Extracellular vesicles: exosomes, microvesicles, and friends. J Cell Biol. 2013;200(4):373-83.

78. Smyth T, Kullberg M, Malik N, Smith-jones P, Graner michael w., Anchordoquy thomas j. Biodistribution and delivery efficiency of unodified tumor-derived exosomes. J Control Release. 2015;10(199):145-55.

79. $\mathrm{W} J, J \mathrm{~K}, \mathrm{~J} Y, \mathrm{D} J, \mathrm{~S} \mathrm{C}, \mathrm{H}$ J, et al. Large-scale generation of cell-derived nanovesicles. Nanoscale. 2014;6(20):12056-64.

80. J K, L L, Y J, N L, T P, C W, et al. Biotransformations of magnetic nanoparticles in the body. Nano Today. 2016;11(3):280-4.

81. Gorth deborah j, Shapiro irving $m$, Risbund makarand v. A new understanding of the role of IL-1 in age-related intervertebral disc degeneration in a murine model. J Bone Miner Reasearch. 2019;34(8):1531-42.

82. Ji ming liang, Jiang $\mathrm{H}$, Zhang xue jun, Shi pei liang, $\mathrm{Li} \mathrm{C}, \mathrm{Wu} \mathrm{H}$, et al. Preclinical development of a micro RNA-based therapy for intervertebral disc degeneration. Nat Commun. 2018;9(1):5051.

83. Liao Z, Li S, Lu S, Lu H, Li G, Ma L, et al. Metformin facilitates mesenchymalstem cell-derived extracellular nanovesicles release and optimizes therapeutic efficacy in intervertebral disc degeneration. Biomaterials. 2021;274(120850). 
84. Brennan meadhbh a, Layrolle P, Mooney david j. Biomaterials functionalized with MSC secreted extracellular vesicles and soluble factors for tissue regeneration. Adv Funct Mater. 2020;30(37).

85. Minasian suzy varderidou, Lorenowicz magdalena j. Mesenchymal stromal/stem cell-derived extracellular vesicles in tissue repair: challenges and opportunities. Theranostics. 2020;10(13):5979-97.

86. Liao Z, Luo R, Li G, Song Y, Zhan S, Zhao K, et al. Exosomes from mesenchymal stem cells modulate endoplasmic reticulum stress to protect againts nucleus pulposus cell death and ameliorate intervertebral disc degeneration in vivo. Theranostics. 2019;9(14):4084-100.

87. Xia C, Zeng Z, Fang B, Tao M, Gu C, Zheng L, et al. Mesenchymal stem cellderived exosomes ameliorate intervertebral disc degeneration via anti-oxidant and anti-inflammatory effects. Free Radic Biol Med. 2019;143:1-15.

88. Caplan H, Olson SD, Kumar A, George M, Prabhakara KS, Wenzel P, et al. Mesenchymal stromal cell therapeutic delivery: translational challenges to clinical application. Front Immunol. 2019;10:1-15. 